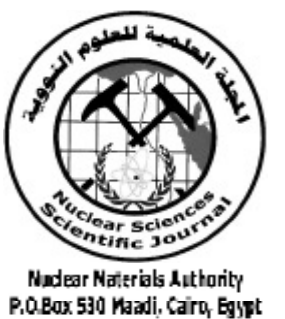

ISSN 2314-5609

Nuclear Sciences Scientific Journal

vol. 3, p $149-168$

2014

\title{
FEATURES CONTROLLING RADIOELEMENTS DISTRIBUTION IN AL AGLAB REGION, NORTH EASTERN DESERT, EGYPT
}

\author{
AHMED A. KHAMIES and REMON R. AYOUB \\ Nuclear Materials Authority, Cairo, Egypt
}

\begin{abstract}
This work is an approach to integrate multi-discipline set of data including geological and remote sensing as well as airborne, ground radiometry and aeromagnetic geophysical data aiming to establish the controlling features of the radioelement potential distribution within Al Aglab area. The investigated area of Al Aglab region is located within the Northern Eastern Desert litho-structural domain where the outcropping rock types comprise: metavolcanics (oldest), quartz diorites, Dokhan volcanics, Hammamat sediments and gabbrogranophyre associations intruded by monzogranite, syenogranite and post granitic dykes (youngest). The granitic rocks display sharp contact with the older pre-existing rock. The radioactive anomalies lay at the intersections between NNW-SSE to N-S and NE-SW to ENE-WSW trending structure lineaments (joints, faults and shear zones) within the syenogranites pluton of G. Al Aglab and along the NE-SW to ENE-WSW trending felsitic dykes, jasperoid veines and pegmatite bodies.

Landsat Thematic Mapper (TM) remote sensing map in great concordance with airborn gamma ray spectrometric data delineate most of the surface geology over the compiled geological map. The extracted structural lineaments are coherent to those inferred from the analytical signal magnetic maps in complete harmony with the NNW-SSE to N-S and NE-SW to ENE-WSW trending fault systems obtained from the ground geological and radiometric investigation. Moreover, different types of alterations such as hematitization, Kaolinitization, chloritization and silicification are recorded within the synogranite, where their distribution is mainly controlled by the intersections between the NNW-SSE to N-S and NE-SW to ENE-WSW trending structural lineaments.

The studied structural lineaments are arranged according to three main trend clusters around NNW-SSE to N-S, NE-SW to ENE-WSW and NW-SE to WNW-ESE directions representing the main factor controlling the emplacement of the different granitic intrusions in Al Aglab area. Moreover, most of these lineaments, as obtained from field measurements, show strike-slip movement criteria within an extensional context. All the recorded mineralized occurrences are related to extensional events that create the necessary space either for mineral entrapment and/or the percolation of the hydrothermal carrying solutions along these structural trends especially at their intersections.

Spectrometric data $(\mathrm{K}, \mathrm{U}$ and $\mathrm{Th})$ shows a very high consistency between the radioelement distributions and the differentiated outlines of different rock types. Results from integrated field studies, Landsat Thematic Mapper (TM) remote sensing data and geophysical data analyses provide important constraints on the tectonic evolution of Al Aglab area and importantly, demonstrate the strength of combining remote sensing data with geophysical data and geological observations in resolving the surface geometry of major fault systems and their impact on the radioelement potential distribution within Al Aglab area.
\end{abstract}

\section{INTRODUCTION}

The investigated area of Al Aglab region is located within the Northern Eastern Desert litho-structural domain between lat. $27^{\circ}$ $15^{\prime}$ and $27^{\circ} 25^{\prime} \mathrm{N}$ and long. $32^{\circ} 55^{\prime}$ and $33^{\circ}$ $05^{\prime}$ E covering an area of about $650 \mathrm{~km}^{2}$. The Eastern Desert has been subdivided into three tectono-stratigraphic domains: South Eastern 
Desert (SED), Central Eastern Desert (CED) and North Eastern Desert (NED). These domains (Fig.1) are separated by two ENEWSW trending tectonic boundaries (shear zones) among them the northern shear zone extending from Qena to Safaga; - separating the NED domain from the CED domain, while the second shear zone running from Aswan to Marsa Alam along Marsa Alam-Idfu road separating the CED domain from the SED domain (Stern and Hedge 1985; El Gaby et al., 1988). Each domain shows a distinct structural fabrics reflecting continuous decrease of the ductile deformation from south to north (Mostafa, 2012).

This tripartite subdivision reflect the following: 1) There is a much higher concentra-

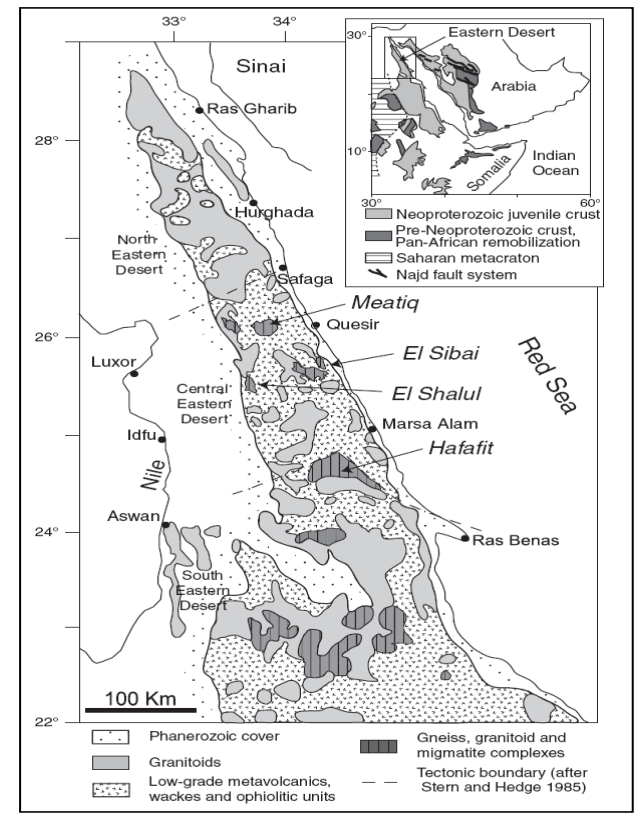

Fig. 1 : Overview of the Eastern Desert, Egypt, showing the distribution of basement rocks with respect to the limits between the basement subdivisions, Southern Eastern Desert (SED), Central Eastern Desert (CED) and Northern Eastern Desert (NED) modified from Moussa et al. (2008). Inset shows the outline of the Neoproterozoic Arabian-Nubian Shield (Stern et al., 2006) with sketch representation of the Saharan Metacraton and the Najd Fault System (Lundmark et al. 2012) tion of granitic rocks in the NED and SED than in the CED; 2) Ophiolites and serpentinites are absent from the NED; 3 ) gneisses are most abundant in the SED(decreasing and disappear to the north of SED); 4) the CED exposes by far the greatest concentration of rocks with strong oceanic affinities, such as ophiolites (Stern and Hedge,1985), 5) Hammamat group is well developed in CED \& NED while it is absent in the SED and 6) Najd deformation being very well developed in Arabia, can be traced into the CED and the SED but not the NED (Stern and Hedge 1985; Sultan et al., 1988; El Gaby et al., 1984; El Gaby et al., 1988; Mostafa,2012). The northern Eastern Desert tectono-stratigraphic domain, where Al Aglab region is located, documented a NESW main structural trend consistent with the post granitic dykes (Mostafa, 2012).

Al Aglab area as a segment of the Northern Eastern Desert of Egypt is dominantly covered by basement rocks mainly composed of Hammamat sediments, Dokhan volcanics and granitoids of late Proterozoic age. According to Dardir et. al., 1972; Abu El-Leil, 1980 and Ayoub, 2003, the granitoids form a continuous magmatic differentiation series in which the younger granites are post-orogenic, originated from calc-alkaline peraluminous magma under an extensional within-plate tectonic setting in the form of small dissected blocks.

In the present work, the geological field measurements of all structural elements (fault, joint, bedding planes, folds, dikes, etc.) are used to improve the interpretation problems in magnetic data. The anomalies are attributed to simple geophysical models such as dykes and faults. The model parameters are determined through a properly designed inversion scheme. The magnetic data were analyzed to determine their specific signatures explaining the overall structural and lithological constraints in comparing them with the vertical lithological variations as well as the structural discontinuities. Moreover, the study aims to throw more light on the structural features controlling the alterations and mineralizations in the catchments 
area and to integrate them with the ground and airborne geophysical (radiometric and magnetic) data as well as satellite remote sensing data with the support of field geological data carried out in Al Aglab area.

For the purpose of this study, the airborne gamma-ray spectrometric maps were processed to show the distribution of radioelements within the studied area and correlated with the geologic and structural maps extracted of the interpretation of Landsat TM images, to establish the lithological and structural characters controlling radioelements distribution. Moreover, (K\%, eUppm and eThppm) radioelements contour maps are superimposed on the reconstructed compiled geological map of the study area to clarify the characteristic geochemical features associated with the different litho-structural rock exposures aiming to delineate the most important radioactive localities in this region.

\section{GEOLOGIC SETTING}

Detailed field investigations have been carried out in Al Aglab area to determine and measured all outcropping rock types as well as the type of their contacts and the prevailing structural elements. Field study revealed that the outcropping rock types in Al Aglab area are represented by metavolcanics, quartz diorites, Dokhan volcanics, Hammamat sediments, gabbro-granophyre associations and younger granites arranged from old to young respectively (Fig. 2). These rock types are later injected by post granitic dykes and veins, while the Quaternary alluvium deposits fill almost all the encountered wadis traversing $\mathrm{Al}$ Aglab area (Fig. 2).

The meavolcanics rocks comprise meta-basalts, meta-dolerites and meta-andesites. The quartz diorites are encountered as small-scattered exposures. The Dokhan volcanics range in composition from andesites to rhyolites and their pyroclastics. The Hammamat sediments are unconformably overlying the Dokhan volcanics; mainly represented by successions of alternating beds of polymictic conglomerates, greywackes and siltstone beds. The gabbrogranophyre association crop out as isolated low hillocks, intruding the surrounding Dokhan volcanics and carries several xenolithes from

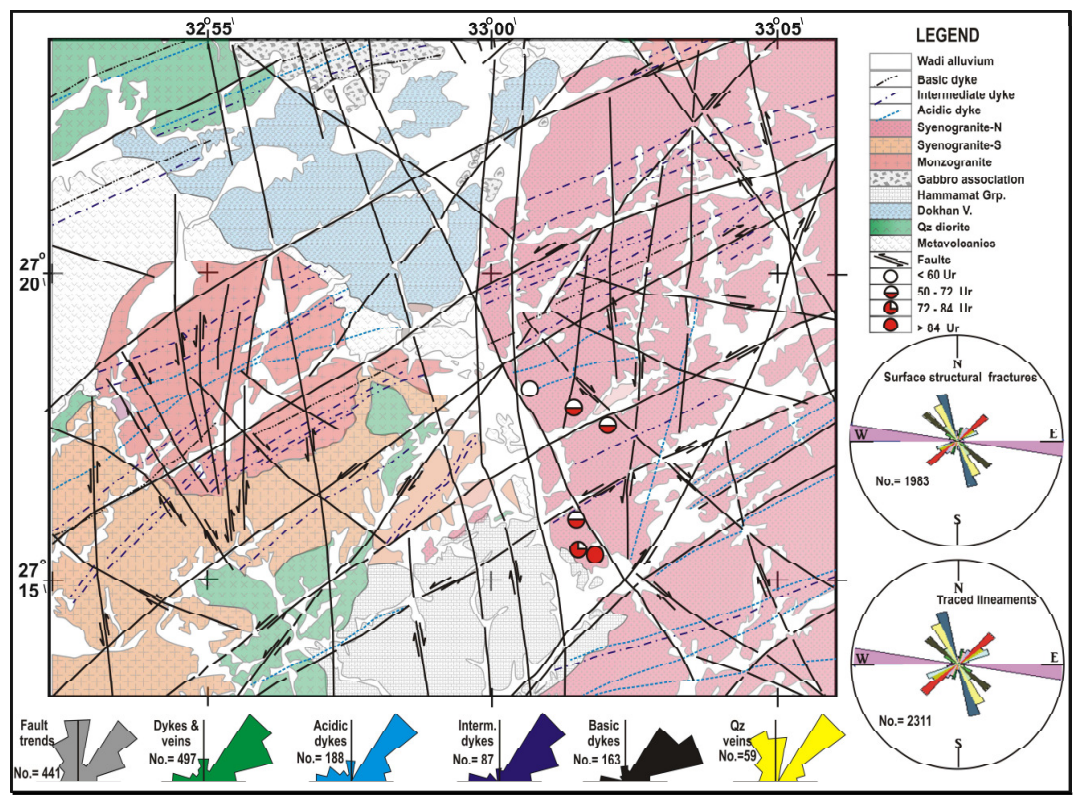

Fig.2 : Compiled geological map of Al Aglab Region, North Eastern Desert, Egypt (Modified after Ayoub, 2003) 
them. They are range in composition from olivine-norite, gabbro-norite, gabbro, pyroxene granophyre and granophyre (Ayoub, 2003).

The younger granites intrude the previously mentioned older rocks. The contact of these granites with their surrounding country rocks is usually intrusive sharp contact with chilled margins that dips gently or steeply away from the granitic pluton (Fig. 3). They form moderate to high mountainous terrain with rough topographic outcrops. Their color ranges from pinkish white to pink and turns to reddish pink when they are stained with hematite along shear zones. They are characterized by bouldery appearance, sheeting structure along the marginal slopes of the granitic plutons (Fig. 4) and taffoni weathering on the inclined surfaces in some peripheral parts (Fig. 5). Occasionally, they include xenoliths of dioritic nature (Fig. 6). Sometimes, the Hammamat sediments occur as roof-pendant masses hanging over the younger granites and form high peaks as recorded at the southern part of the mapped area (Fig. 7). The younger granites emplacement ended by multistages of dyke injections ranging in composition from acidic, intermediate to basic following the NE-SW, ENE-WSW and E-W dominant structural trends (Roz,2001; Ayoub, 2003 and Abd El-Hadi,2006).

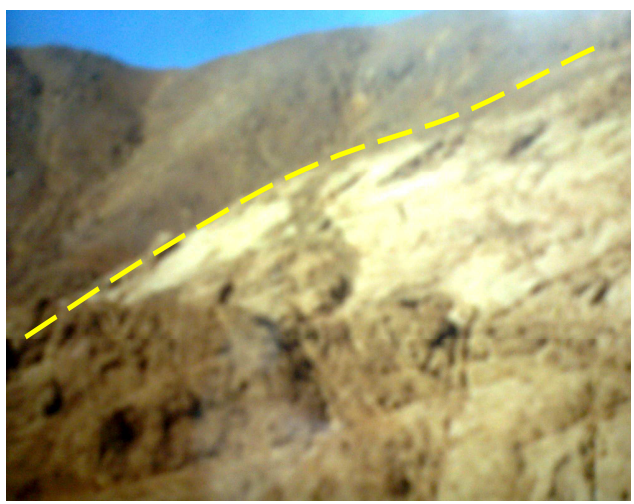

Fig. 3 : Intrusive sharp contact between the younger granite \& Dokhan volcanic country rocks, Al Aglab area

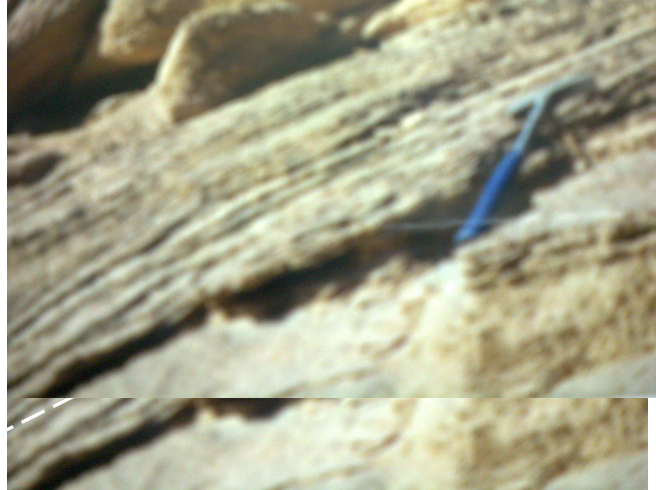

Fig.4 : Sheeting structure in the younger granites, $\mathrm{Al}$ Aglab area

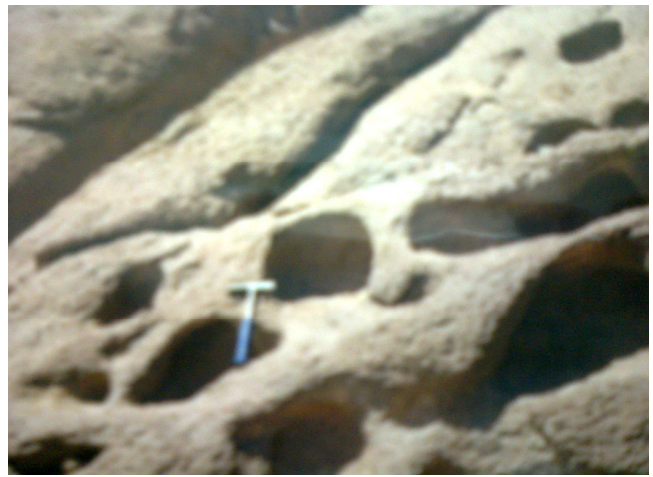

Fig.5: Taffoni weathering in the younger granites Al Aglab area

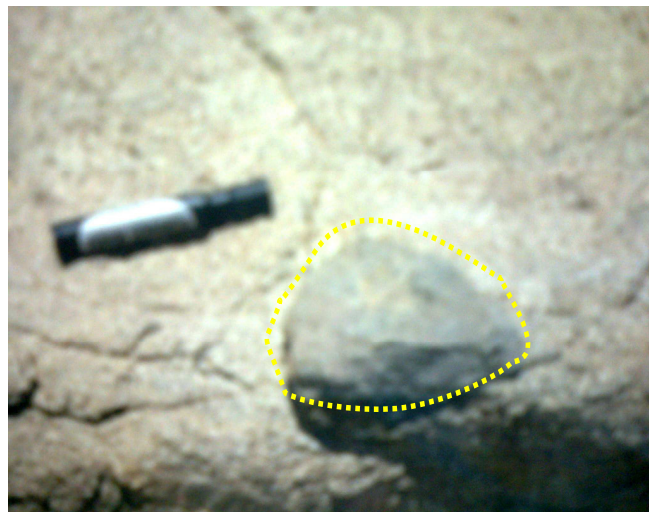

Fig.6 : Xenoliths of Dokhan volcanic within younger granites, Al Aglab area 


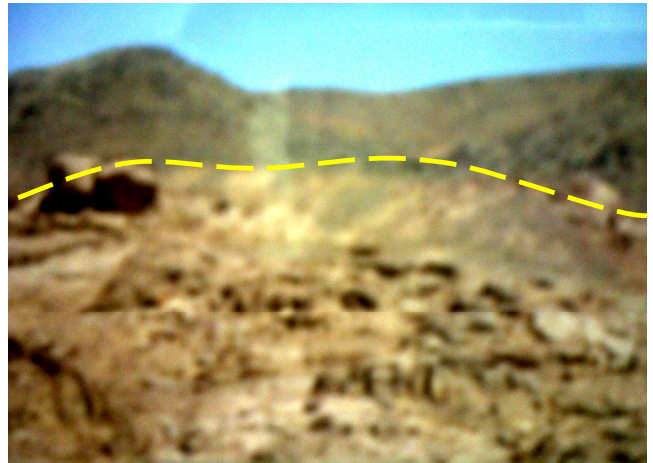

Fig.7 : Roof-pendant of Hammamat on the younger granites , Al Aglab area

Younger granites, in the study area, represent successive pulses from the same magma chamber and could be classified into: monzogranite and syenogranite (Ayoub, 2003). The monzogranite represents the least evolved member of this magmatic series, followed by syenogranite that represents the most evolved phase of the series (Ayoub, 2003).

The field observations revealed that the monzogranites of W. Lissan El Baqara are the oldest ones while the syenogranite in south W. Lissan El Baqara and Al Aglab ridge are the youngest. These younger granites were intruded within the preexisting metavolcanics, quartz diorites, Dokhan volcanics, Hammamat sediments, gabbro-granophyre associations. The younger granites are affected by many types of faults arranged according to ENE-WSW, N-S and NNW-SSE directions as recorded from the detailed field investigation. The ENE-WSW trending ones represent the most predominant regional trend that extends for several kms. The ENE-WSW trending fault planes carry evidences of cyclic reactivation as indicated from the recorded movement criteria that could reflect a contemporaneous association with cyclic injections of different acidic rocks as well as the vary colored quartz veins and intensive phase of hydrothermal activities. The granite rocks within these zones are highly altered and are associated in places with pegmatite bodies (Fig. 8). Moreover, the highest radioactive anomalies are recorded along the ENE-WSW trending shear zone when intersecting with the NE-SW ones where they reach up to $84 \mathrm{Ur}$. In addition to that, the joint measurements show three trend clusters arranged due to NE-SW, NW-SE and $\mathrm{E}-\mathrm{W}$ directions in decreasing predominance order (Figs. 9).

\section{STRUCTURAL DATA}

The investigated area forms a part of the Arabo-Nubian basement exposures that situated at the northern Eastern Desert. Accordingly, its structural pattern is strongly related

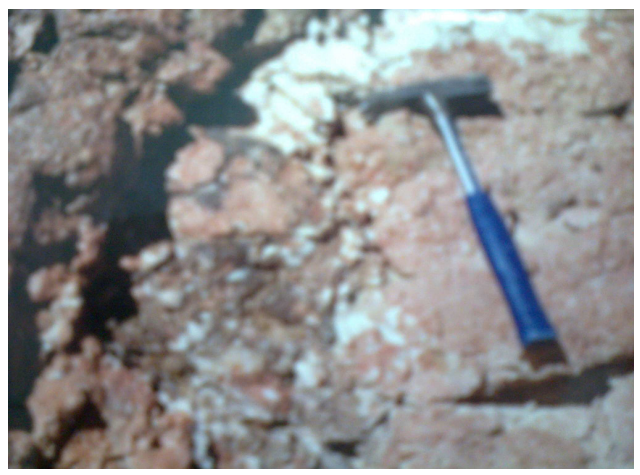

Fig. 8: Pegmatite pockets in the younger granites, Al Aglab area

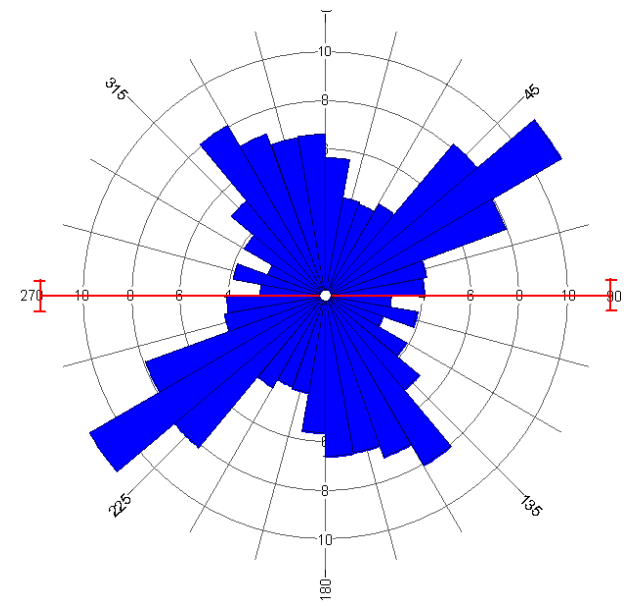

Fig.9 : Frequency distribution rose diagram of all fractures, Al Aglab area 
to that of the late Neoproterozoic pan-African structural events dominating within the northern Eastern Desert. It is mainly represented by polycyclic extensional shear zones mainly coinciding with the documented NE-SW main structural trend in consistent with the post granitic dykes as well as the reactivation of both Eastern Desert Shear Zones (EDSZ) and Najd style left lateral strike-slip shear system (Mostafa, 2012). The intersection of these structural trends divide the northern Eastern Desert basement rocks into faulted blocks representing the essential structures of the first order outlined in the arched uplift of the basement complex described by Sabet et al. (1976), Abu El-Liel (1980) and Ayoub (2003).

Most of the tectonic models of the Eastern Desert relate the Older granites to plate convergence and magma generation above subduction zones and the Younger granites to crustal extension related to orogenic collapse and/or post-orogenic rifting (Stern et al., 1984; Greiling et al., 1994; Farahat et al., 2007; Moussa et al., 2008). The development of regional strike-slip shear zones, in some models, is interpreted to have facilitated emplacement of the syn-orogenic plutons (e.g. Fritz et al., 1996; Bregar et al., 2002).

For the purpose of this work, 1045 joints have been measured among the various rock types in Al Aglab area, in addition to 441 minor faults 998 dykes and 59 veins (Figs. $2 \& 10-17)$. The study area is cross-cut by various dykes (aplite, felsites, andesites and dolerites) and quartz veins with different striking according to NE-SW, N-S, ENE-WSW, WNW-ESE and NNW-SSW (Fig.2).

The structural measurements of fractures, faults, joints and dykes show wide trend pattern but dominated by four trend clusters oriented due to NE-SW, NW-SE, NNW-SSE and N-S directions (Figs. 2\&9). The geometrical distribution of fault strikes presented on Figure (9) show that faults, in spite of their type, are arranged according to three main trend clusters around N-S (NNE-SSW-NNW-SSE), NE-SW and NW-SE directions respectively

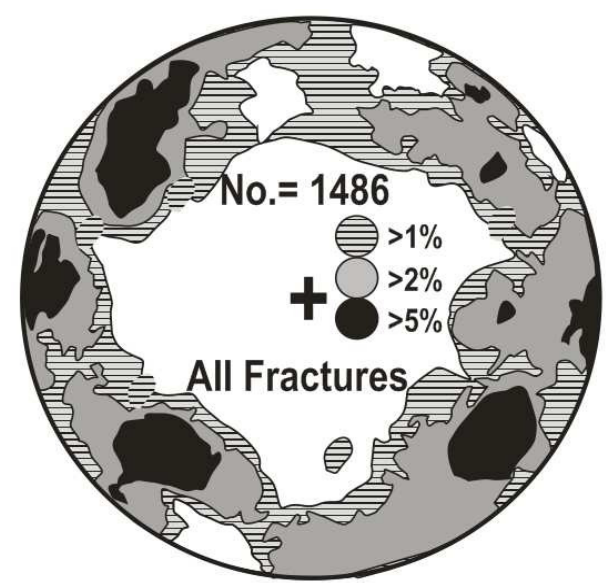

Fig.10: Poles to all fractures lower hemisphere density contour diagrams, Al Aglab area

in addition to fairly E-W one. Moreover, the analysis of the recorded movement criteria on fault planes $($ No. $=441)$ reflect cyclic extensional strike-slip deformational regime corresponding to a multi-directional NW-SE \& NE-SW oriented extension associated with almost all recorded dyke and vein trends in addition to an older NNE-SSW \& WNW-ESE to E-W trending pair of extension characterizing the measured strike-slip and normal fault sets that arranged in NE-SW, N-S, ENE-WSW and NNW-SSE trends according to their length and number proportions in decreasing order (Figs. 2,9 \&10).

Dykes trend analysis shows NE-SW main trend cluster in additional to fairly NNW-SSE \& WNW-ESE trending ones. Structural studies of the deformed and undeformed dykes reveal that they are non-Andersonian dykes that exploited pre-existing fractures (Caputo, 2005). In contrast, dykes crosscutting competent unfoliated rock lithologies are attributed to neo-formed fractures initiated perpendicular to the minimum stress axis so that their attitude is closely related to the regional tectonic stress field (Faure et al., 1996). Undeformed dykes display $\mathrm{N} 15^{\circ} \mathrm{E}, \mathrm{N} 55^{\circ} \mathrm{E}$ and $\mathrm{E}-\mathrm{W}$ strikes; whereas the deformed ones show $\mathrm{N} 65^{\circ} \mathrm{E}$ or $\mathrm{N} 100^{\circ} \mathrm{E}$ trends with dextral and sinistral shear 
senses, respectively. These structural data point to reactivation of pre-existing fractures either as tensional cracks (undeformed dykes) or transtensional shear zones (deformed dykes).

Dykes could be structurally grouped into three main trend clusters due NE-SW, ENEWSW and E-W directions (Fig.2 \& Table 1). The NE-SW striking dykes is the dominant dyke trend among the study area and recorded cutting through almost all structural features i.e. the most recent one and corresponding to NW-SE trending extensional event. This is the case of the post granitic dykes that run as parallel to sub-parallel swarms closely coincide with the prevailing fracture systems, fault trends and shear zones among the study area (Fig.2). Table (1) shows the main directional trends percentages of faults, dykes and veins, whereas rose diagrams of different dykes and veins (acidic dykes, intermediate dykes, basic dykes and quartz veins) based on their number wise are presented on Fig. (2).

The density distribution of poles to joint strikes presented on Figures (11-17) show that joint, in spite of their type, are arranged according to two main trend clusters around NE-SW and NW-SE directions respectively in addition to fairly N-S (NNE-SSW-NNWSSE) and E-W ones. Meta-volcanics is characterized nearly by the vertical E-W trending joints (No.=100), whereas the Qz-diorites exhibit the WNW-ESE, N-S \& E-W trends for the measured 155 joints (Figs. 12\&13 respectively). The poles to all joints (175) measured in Dokhan volcanics as well as those of Hammamat sediments (115) characterize NS, NE-SW \& ENE-WSW trend clusters (Figs. $14 \& 15$ respectively). Joint strikes measured in the younger granites are arranged according to NE-SW and around E-W trends in monsogranites whereas they are oriented around NE-SW and NW-SE direction in the syenogranites (Figs. 16\&17 respectively).

The main mineralized zone is hosted in a shear zone adjacent to and/or within the younger granitic rocks at the intersection of the NE-SW, NNW-SSE \& ENE-WSW structural trends (Fig.2). The mineralization history could be correlated with the progressive deformation of these shear zones and the granitic intrusion. It has been found that the mineralized occurrences are just one of a number of intrusive, extrusive and hydrothermal events occurring during major extension deformational regime in which the extensional stress components transfer along and reactivate the pre-existing ENE-WSW to E-W trending fractures.

\section{REMOTE SENSING DATA ANALYSIS}

Landsat Thematic Mapper (TM) data for Al Aglab area was processed for geological

Table 1: The main directional trend percentages of faults, dykes and veins of Al Aglab area, North Eastern Desert, Egypt

\begin{tabular}{lrrrrrrr}
\hline Trends & $\begin{array}{r}\text { Fault } \\
\text { Length } \\
\text { Wise }\end{array}$ & $\begin{array}{r}\text { Fault } \\
\text { Number } \\
\text { Wise }\end{array}$ & $\begin{array}{r}\text { Veins } \\
\text { and } \\
\text { Dykes }\end{array}$ & $\begin{array}{r}\text { Acidic } \\
\text { Dykes }\end{array}$ & $\begin{array}{r}\text { Intermediate } \\
\text { Dykes }\end{array}$ & $\begin{array}{r}\text { Basic } \\
\text { Dykes }\end{array}$ & $\begin{array}{r}\text { Quartz } \\
\text { Veins }\end{array}$ \\
\hline E-W & $\mathbf{3 . 7 0}$ & $\mathbf{6 . 1 9}$ & $\mathbf{1 2 . 6 0}$ & 15.7 & 15 & 12 & $\mathbf{6 . 7}$ \\
WNW-ESE & $\mathbf{5 . 0 4}$ & $\mathbf{6 . 1 9}$ & $\mathbf{5 . 3 0}$ & 11.4 & $\mathbf{5}$ & $\mathbf{1 . 6}$ & $\mathbf{6 . 7}$ \\
NW-SE & $\mathbf{8 . 9 2}$ & $\mathbf{7 . 9 6}$ & $\mathbf{2 . 8 0}$ & $\mathbf{5 . 7}$ & $\mathbf{0}$ & $\mathbf{0}$ & $\mathbf{1 0}$ \\
NNW-SSE & $\mathbf{1 6 . 4 4}$ & $\mathbf{1 4 . 1 6}$ & 4.50 & 2.9 & $\mathbf{0}$ & $\mathbf{2 . 4}$ & $\mathbf{2 0}$ \\
N-S & $\mathbf{2 0 . 3 0}$ & $\mathbf{2 0 . 3 5}$ & $\mathbf{8 . 6 0}$ & $\mathbf{1 0}$ & $\mathbf{5}$ & $\mathbf{6 . 4}$ & $\mathbf{1 6 . 6}$ \\
NNE-SSW & $\mathbf{5 . 6 0}$ & $\mathbf{5 . 3 2}$ & $\mathbf{3 . 3 0}$ & $\mathbf{0}$ & $\mathbf{5}$ & $\mathbf{5 . 6}$ & $\mathbf{0}$ \\
NE-SW & $\mathbf{2 0 . 9 6}$ & $\mathbf{2 3 . 9 0}$ & $\mathbf{3 3 . 5 0}$ & 35.7 & $\mathbf{4 0}$ & $\mathbf{3 2}$ & $\mathbf{3 0}$ \\
ENE-WSW & $\mathbf{1 9 . 0 5}$ & $\mathbf{1 5 . 9 3}$ & $\mathbf{2 9 . 4 0}$ & $\mathbf{8 . 7}$ & $\mathbf{3 0}$ & $\mathbf{4 0}$ & $\mathbf{1 0}$ \\
\hline
\end{tabular}




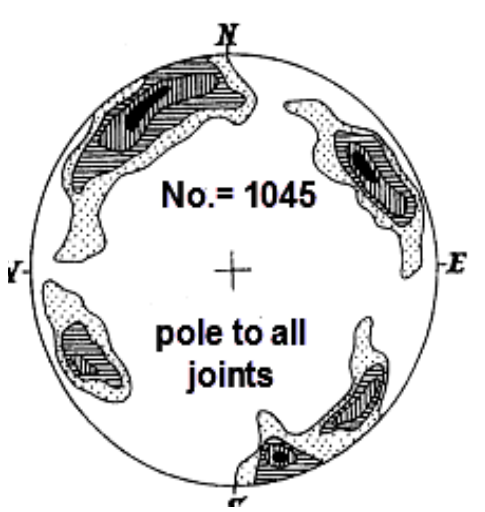

Fig.11: Poles to all joints lower hemisphere density contour diagrams, Al Aglab area

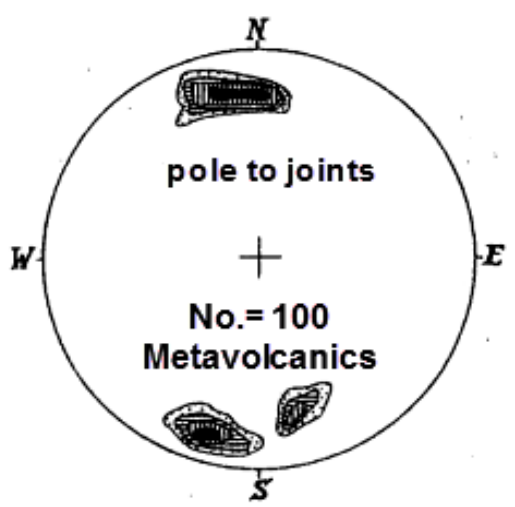

Fig.12 : Poles to all joints lower hemisphere density contour diagrams, Metavolcanics, $\mathrm{Al}$ Aglab area

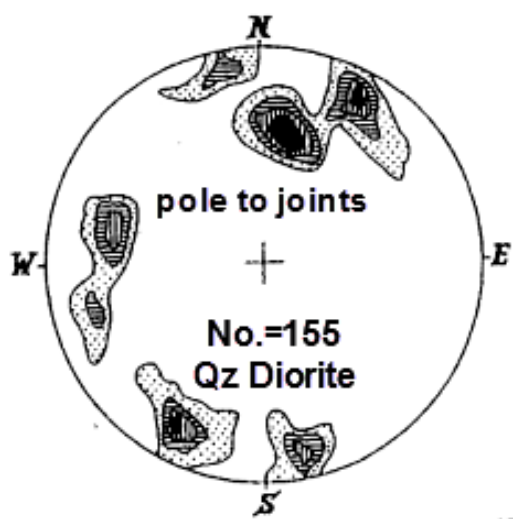

Fig. 13: Poles to all joints lower hemisphere density contour diagrams, Qz-diorite, Al Aglab area

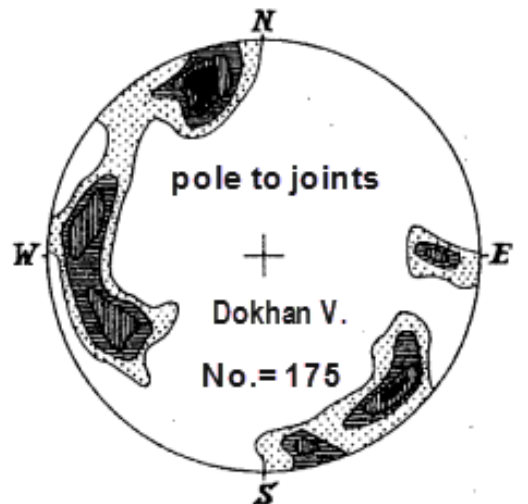

Fig. 14: Poles to all joints lower hemisphere density contour diagrams, Dokhan V., Aglab area

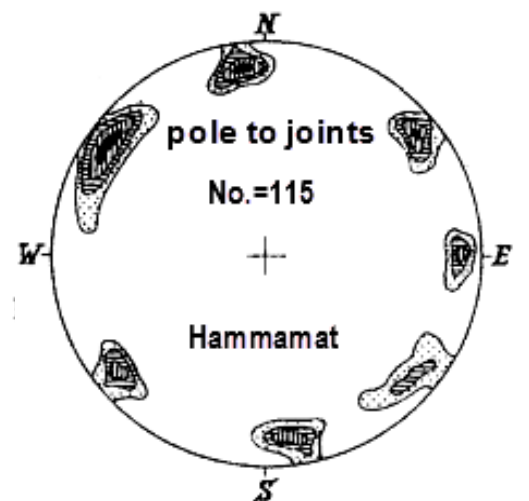

Fig.15: Poles to all joints lower hemisphere density contour diagrams, Hammamat, Aglab area

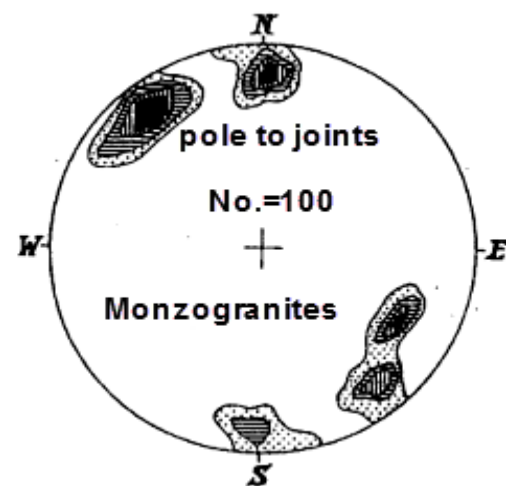

Fig.16: Poles to all joints lower hemisphere density contour diagrams, Monzogranites, Aglab area 


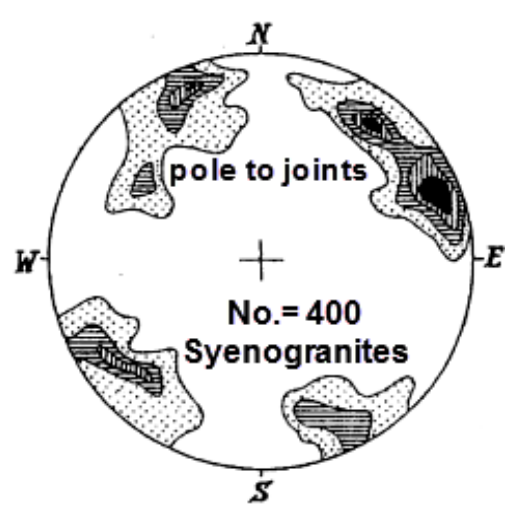

Fig. 17: Poles to all joints lower hemisphere density contour diagrams, Syenogranites, Aglab area

and structural mapping using the ENVI Version 3.4. A single Landsat TM scene (Path 175 / 41) has been geometrically corrected and radiometrically balanced and digitally processed.

The aim of applying the advanced technique of image processing in this work is to help in the geologic and structural interpretations of the study area as well as its uranium potentiality.

The interpretation of the colored fused image identifies and discriminates in detailed many of the lithologic information that could match with the different exposed rock types in the study area. The detailed visual characteristics of each rock type that appear on the prepared fused image will be discussed in terms of their lithological characterization as well as the deduced structural lineaments interpretation based on colour differences at the boundaries of contrasting lithological units breaks in crystalline rock masses and visible faults, among the various rock types in $\mathrm{Al}$ Aglab area.

Different lithologies have been identified from Landsat TM image (Fig. 18) along with the geological map based on analysis of the visual interpretation of colour composites. On the basis of tone and texture difference, morphology and structure, the separation of a crystalline basement complex has been inferred (Fig.19). Seven major lithological

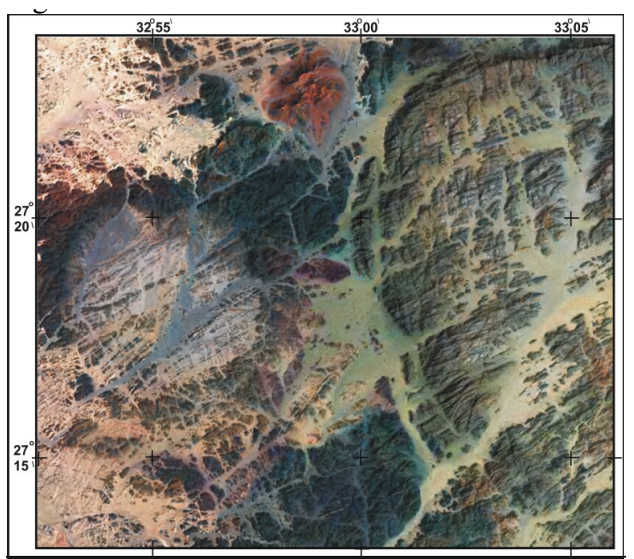

Fig.18: False colour composite Landsat image, Al Aglab area, north Eastern Desert, Egypt (After Egyptian Remote Sensing Centre, 1992)

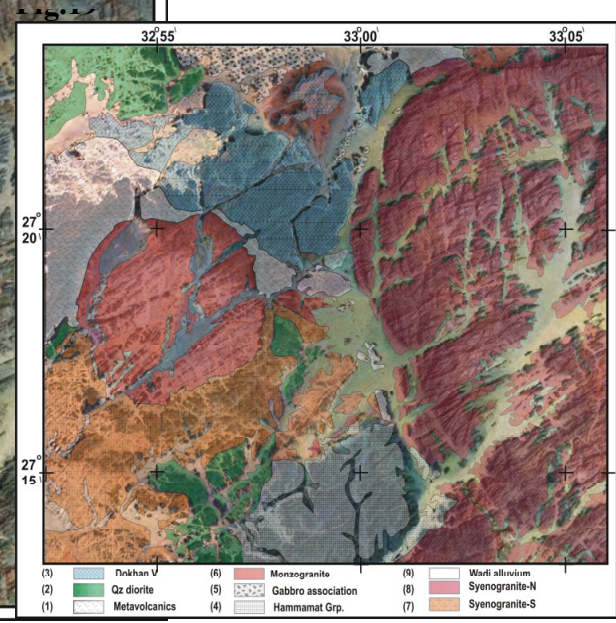

Fig. 19: Compiled geological map of Al Aglab area inferred from the Landsat image (lithological characters)

units corresponding to metavolcanics, quartz diorites, Dokhan volcanics, Hammamt sediments, gabbro-granophyre association monzogranites and syenogranites have been deduced and identified (Fig.19).

Metavolcanics appear on the processed Landsat TM image in dark brown color (Fig.18). They are dissected by numerous tributaries of wadies directed predominantly in the NE-SW directions. They are characterized by their low reflectivity (low DN values) to the electromagnetic spectrum due to their 
high contents of mafics and iron-rich minerals. Dokhan volcanics appear on Landsat TM image in dark bluish colour (Fig.18). Hammamat sediments have dark greenish to dark greyish colors in the prepared fused image. They are invaded in some places by the younger granites in the southern part of the mapped area. Gabbro-granophyre association appear on Landsat TM image in yellow color (Fig.18). Monzogranites are appear on the fused image in reddish grey color, while the syenogranites have dark greenish to dark greyish colors in the prepared fused image. Quaternary sediments are well recognized on the image by their pale brown colors (Fig.18).

The lineaments are the surface expression of fractures, faults, or escarpments. From the visual inspection of the extracted lineaments and their correlation with the satellite, it was noticed that the lineaments are indicated on the landsat images by rock-tonal or topographic alignments (Figs.18\&20). Figure (20) shows the extracted lineaments in Al Aglab area. Both mega-lineaments (10-100 km length) and macro-lineaments (2-10 km length) delineate wadis and their branches in most cases (Fig.20). The NE-SW, NW-SE to NNW-SSE and WNW-ESE are the dominant trend clusters inferred from wadis and the contact between granites and surround rocks (Fig.20). On regional scale, the extracted structural lineaments (based on Landsat image; Fig.20) and the structures elements demonstrated on the geological map (Figs.2\&21) are coherent. Both record NNW-SSE, to N-S, NE-SW to ENE-WSW as main regional structural trends associated with WNW-ESE to E-W and NWSE minor ones.

Results obtained from the processed (TM) Landsat data of Al Aglab area for both lithological and structural purposes are completely coherent with those defined from the field geological data carried out in Al Aglab area. Landsat Thematic Mapper (TM) remote sensing map delineate most of the outcropping rock types in great concordance with the compiled surface geological map whereas

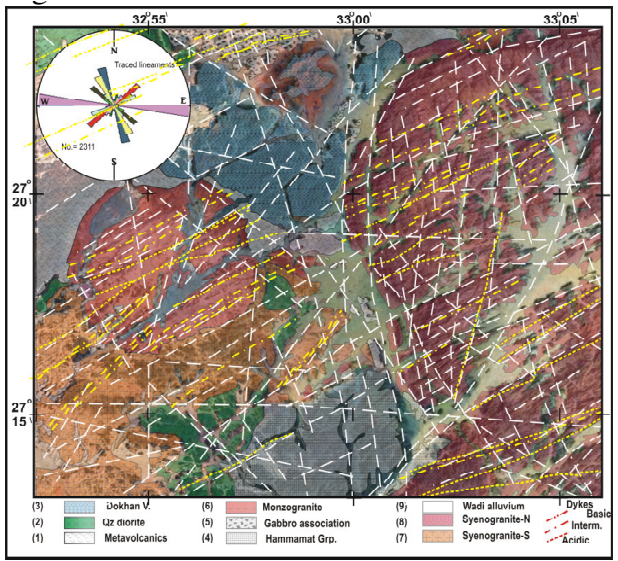

Fig.20: Structural lineament map of Al Aglab area deduced from the Landsat image (linear characters)

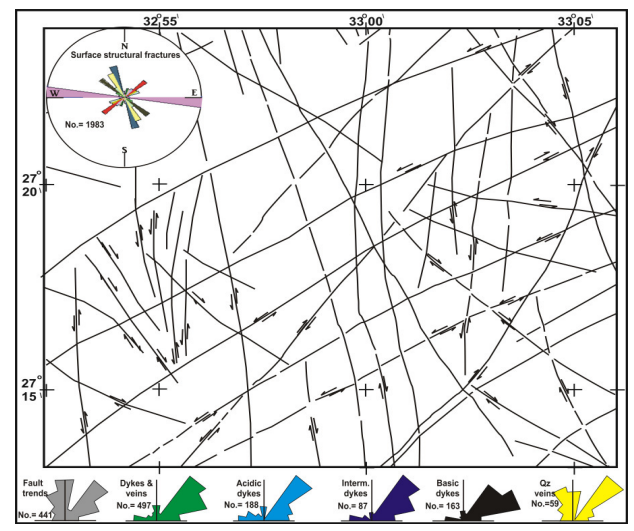

Fig.21: Structural map of Al Aglab area deduced from the measured surface structural features

the extracted structural lineaments are coherent to the NNW-SSE to N-S and NE-SW to ENE-WSW trending fault systems obtained from the field geological data in complete harmony. Moreover, different types of alterations such as hematitization, kaolinitization, chloritization and silicification are recorded within the syenogranites, where their distribution is mainly controlled by the intersections between the NNW-SSE to N-S and NE-SW to ENE-WSW trending structural lineaments.

\section{GEOPHYSICAL DATA}

Aeromagnetic and airborne gamma-ray geophysical data produced in Aero-Service 
(1984a\&b) have been used. The aeromagnetic and the airborne gamma-ray spectrometry data are conducted along parallel flight lines that were oriented in a NE-SW direction at one $\mathrm{km}$ spacing, while the tie lines were flown in a NW-SE direction at $10 \mathrm{~km}$ intervals. The aeromagnetic data are of great importance in delineating the basement structures whereas the airborne gamma-ray survey provided important information about the distribution of $\mathrm{K}, \mathrm{U}$ and $\mathrm{Th}$ in the area.

\section{Aeromagnetic Data}

The aeromagnetic data of the study area was transformed to the wave-number domain. Reduction to the north magnetic pole was performed at the first stage of processing (Fig.22). In order to delineating the structural framework of the area the analytical signal (Nabighian, 1972, 1974\&1984) and low-passfiltered was carried out (Figs. 23\&24). The $\mathrm{N}-\mathrm{S}$ and ENE-WSW, NE-SW fault patterns as delineated from Landsat image match well with the low amplitude magnetic contour patterns (Fig. 25).

Magnetic anomaly analysis can provide additional information for possible subsurface geometry (shape) of Al Aglab intrusions. The interpretation of these magnetic data is complex because they usually reflect contributions from several sources.

Magnetic anomaly map (Fig. 22) contains a number of features (anomalies, structures, etc.) which are superimposed on each other. Since one type of anomaly often masks another, the need arises to separate the various features from each other. low-pass-filtered magnetic anomaly is prepared to have a better comparison between the magnetic map and the subsurface geometric (Fig. 23). Low pass component (regional) of data aeromagnetic map have become available by using Geosoft software. It shows a magnetic low over the northern part of Al Aglab granite pluton. There are some interesting correlations of anomaly patterns with individual granite intrusions.

Magnetic anomaly is the semi-circular

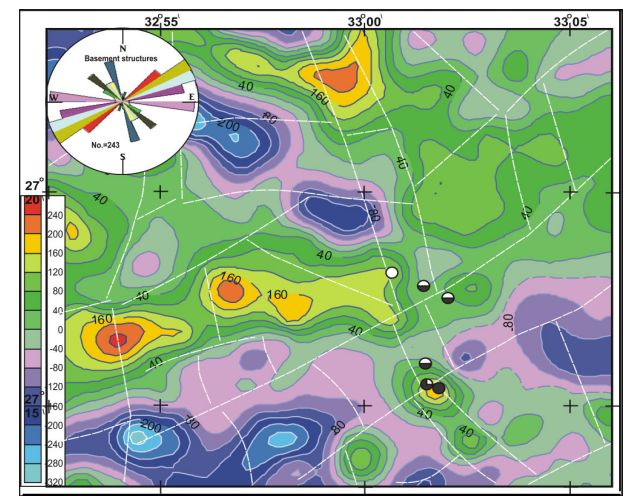

Fig.22: Reduced to pole (RTP) aeromagnetic map, Al Aglab area, north Eastern Desert, Egypt

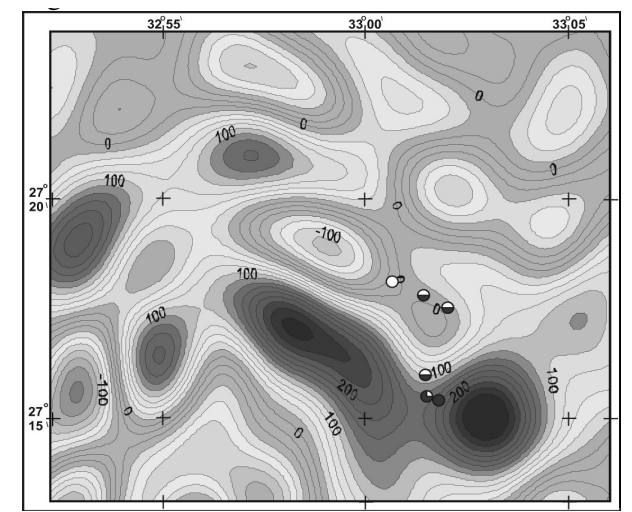

Fig.23: low-pass-filtered map, Al Aglab area, north Eastern Desert, Egypt

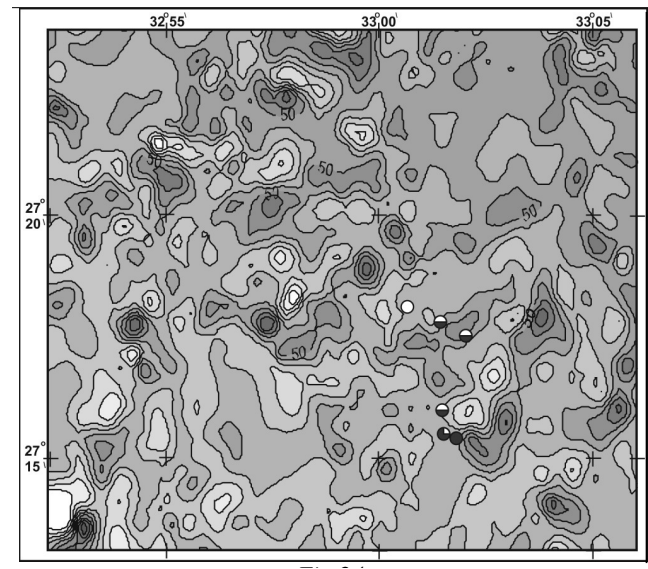

Fig.24: Analytical signal map, Al Aglab area, north Eastern Desert, Egypt 


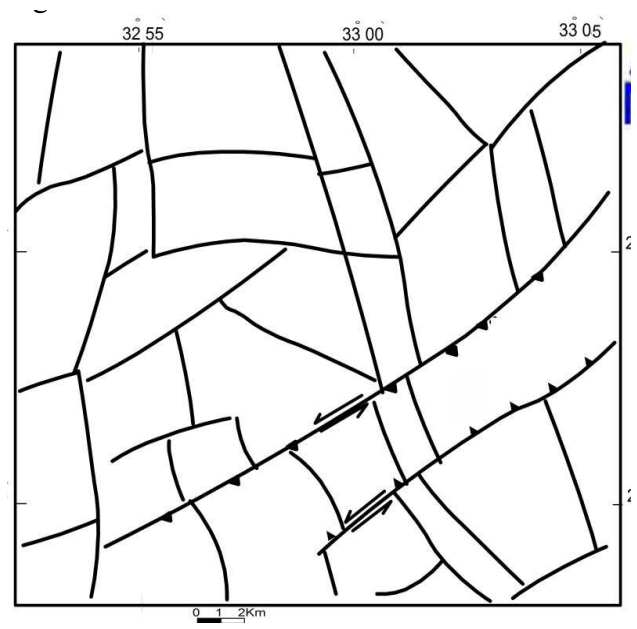

Fig.25: Regional tectonic map, Al Aglab area, north Eastern Desert, Egypt

magnetic high coinciding with the southern part of the Al Aglab granite pluton. The sharp magnetic gradient is indicative of a NE-SW fault that dividing Al Aglab granite pluton. It might have controlled the emplacement of this pluton. The magnetic low is surrounded by magnetic highs due to the surrounding younger granites. The sharp gradient between highs and lows suggests a contact with considerable change in susceptibility across it due to variations in the magnetic constituent of the two rock types younger granite and Dokhan volcanics.

The area has been subjected to multiple tectonic events represented by faults during various stages of its evolution. The oldest sets of faults trending $\mathrm{N}-\mathrm{S}$ and $\mathrm{E}-\mathrm{W}$ are cut by earliest NW- SE and NE-SW faults relate to Red Sea rift. They separate the northern and southern parts of the pluton. These younger faults control the distribution of numerous radioactive anomalies.

\section{Airborne Gamma-ray Spectrometry Data}

Radioelements contour maps are reconstructed and superimposed on the geological map of the study area to determine the geochemical characteristics and evaluate the litho-structural features of the different rock exposures hopping to delineate an expected potential uranium targets.

The younger granites are discriminated by their high radioactivity (Fig. 26) and the superimposed contour lines have two specific trends (NNE-NSW and NNW-SSE). These granites are delineated carefully by total-count level of $10 \mathrm{Ur}$ and increase gradually towards the inner zone of the pluton. Contour line values of 7.5 Ur are associated mainly with Hammamat sediments. However, the metavolcanic rocks are delineated by total-count level of $2.5 \mathrm{Ur}$.

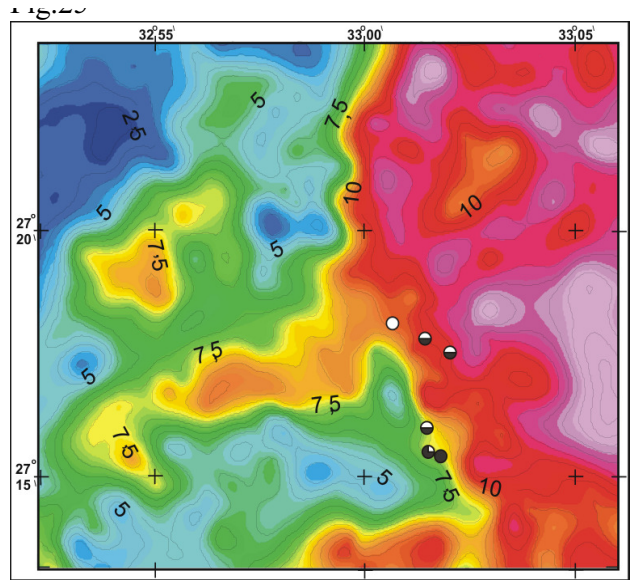

Fig. 26: Airborne total count contour map (in Ur), Al Aglab area, north Eastern Desert, Egypt

The K-anomaly zones (Fig.27) are aligned along NNE-SSW, NNW-SSE, NW-SE and NE-SW trends. They follow the regional structural trends, where hydrothermal alterations associated with potassium enrichment occurs. These alteration zones are frequently associated with the formation of various types of mineral deposits encountered in the area e.g. copper deposits (Dardir et. al., 1972).

The shapes and trends defined by the contour lines on the eU distribution map (Fig.28) show that the younger granites is characterized by relatively high concentration values. The uranium range (4-7 ppm) is located over the younger granites to the northern part of pluton meanwhile it has a range of (4-5 ppm) at the southern part. It is encountered as zones 


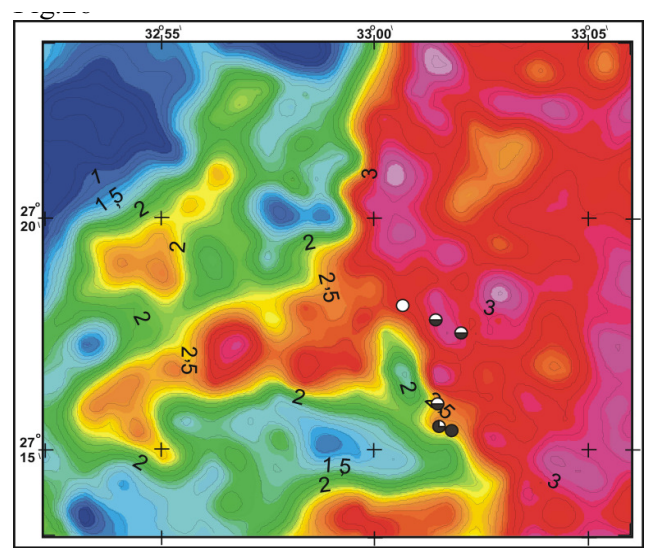

Fig.27: Airborne potassium contour map (in \%), $\mathrm{Al}$ Aglab area, north Eastern Desert, Egypt

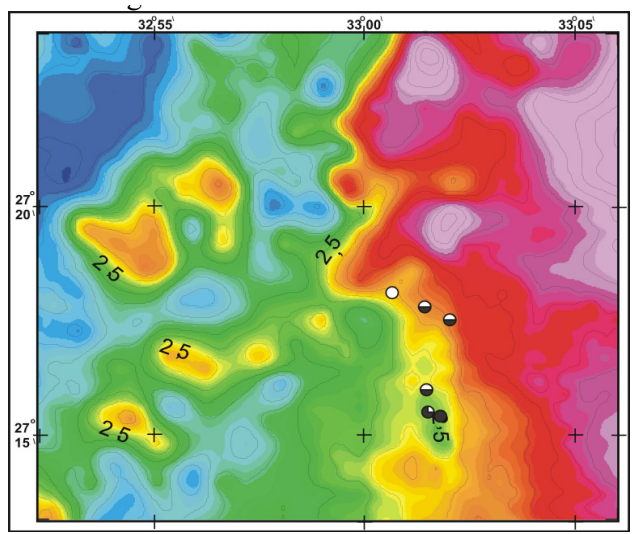

Fig.28 Airborne equivalent uranium contour map (in ppm), Al Aglab area, north Eastern Desert, Egypt

with different shapes, sometimes controlled by the main fault trends in the study area.

Thorium content (Fig. 29) is constant and when thorium content increases reflecting the fractionation in this type of granites. A little fractionation toward the south was detected in the main granitic pluton where the thorium content varies from 10 to $20 \mathrm{ppm}$ meanwhile it less than $15 \mathrm{ppm}$ at the northwestern part.

The eU/eTh contour map (Fig. 30) confirms the presence of little fractionation toward the south in the main granitic pluton. $\mathrm{eU} / \mathrm{eTh}$ ratio (lower than 0.3 ) coincides with the younger granite. The highest eU/eTh

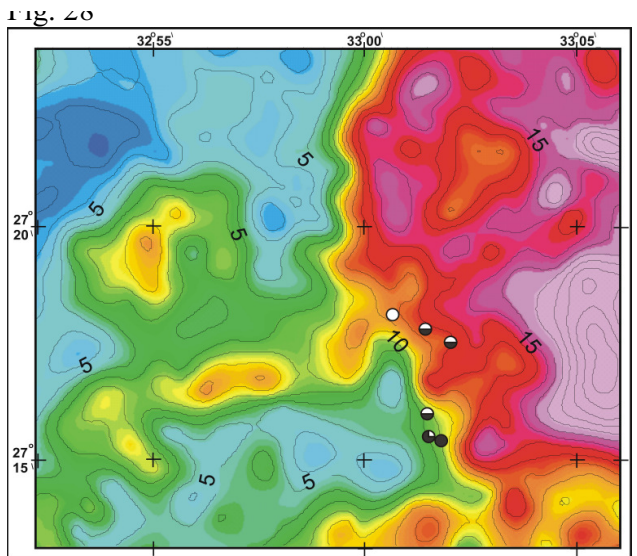

Fig.29: Airborne equivalent thorium contour map (in ppm), Al Aglab area, north Eastern Desert, Egypt

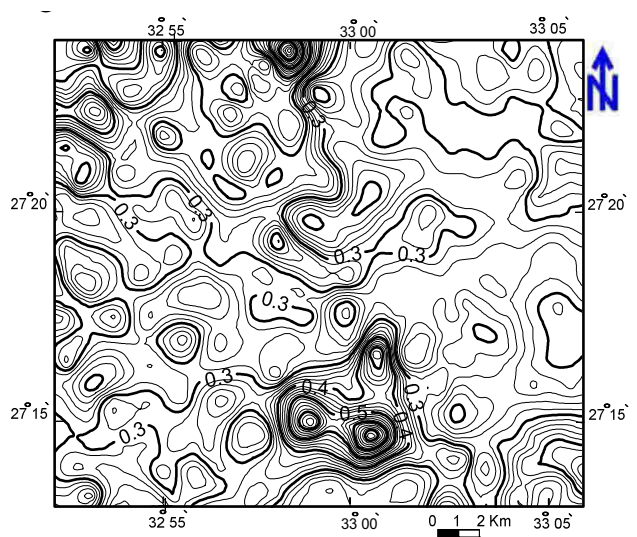

Fig. 30: Airborne eU/ eTh ratio contour, Al Aglab area, north Eastern Desert, Egypt

anomalies reaching up to 0.7 , trending in the $\mathrm{N}-\mathrm{S}$ direction and coincide with the Hammamat sediments. Another highly elongated $\mathrm{eU} / \mathrm{eTh}$ anomalies, which reached 0.7 at the intersections of both the NW-SE and NE-SW main faults.

The low $\mathrm{eTh} / \mathrm{K}$ ratio can be easily detected at the alteration zone. The $\mathrm{eTh} / \mathrm{K}$ contour map (Fig. 31) shows that the younger granites are clearly discriminated from the shear zone by their $\mathrm{eTh} / \mathrm{K}$ moderate levels. Two high $\mathrm{eTh} / \mathrm{K}$ anomalies associated with the granites, reaching values of about 14 . There is one $\mathrm{eTh} / \mathrm{K}$ anomaly located at the southwestern part of the study area and associated with the younger 


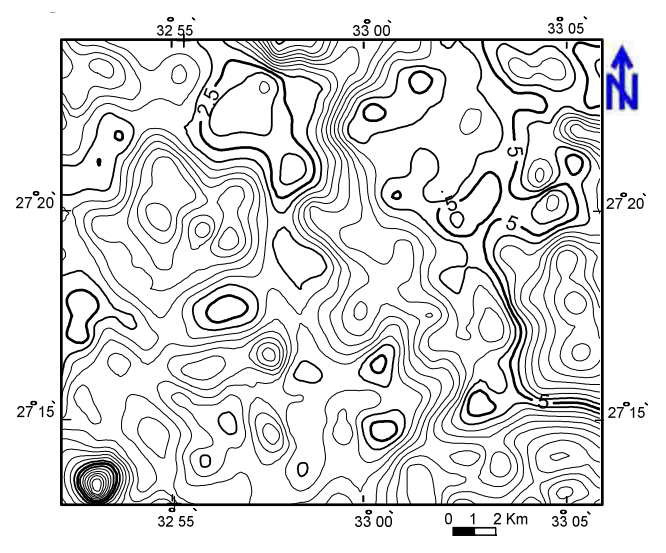

Fig. 31: Airborne eTh/K ratio contour, $\mathrm{Al}$ Aglab area, north Eastern Desert, Egypt

granites. Another high anomaly, reaching about 10 , coincides with the shear zone and defines an elongated belt in the E-W direction.

The highest anomalies of $\mathrm{eTh} / \mathrm{K}$ ratio are mostly associated with the pegmatitic segregations, being intruded into the monzogranite, and having high eTh values. Meanwhile, the syenogranite has low $\mathrm{eTh} / \mathrm{K}$ ratio due to its high $\mathrm{K}$ content relative to its eTh content.

The eU/K ratio contour map (Fig. 32) shows coincidence with the high eU concentrations. Very high anomalies reaching 38 appear as closed and dense contour lines mainly over the shear zone. The younger granites are characterized by a low range of the eU/K ra- tio due to increase in eU with a simultaneous increase in $\mathrm{K}$ concentrations. The eU/K ratio correlates positively with eU concentrations and negatively with $\mathrm{K}$ concentrations for the shear zone. These correlations are weak in the case of syenogranite. Figure (33) shows bar diagram for radiometry of different rock types helping in the identification and registration of the most important radioactive localities in this region.

It has been found that the basement tectonic map inferred from the analytical signal magnetic maps is coherent with the regional structural trends deduced from the Landsat Thematic Mapper (TM) remote sensing map in complete harmony with NNW-SSE to N-S

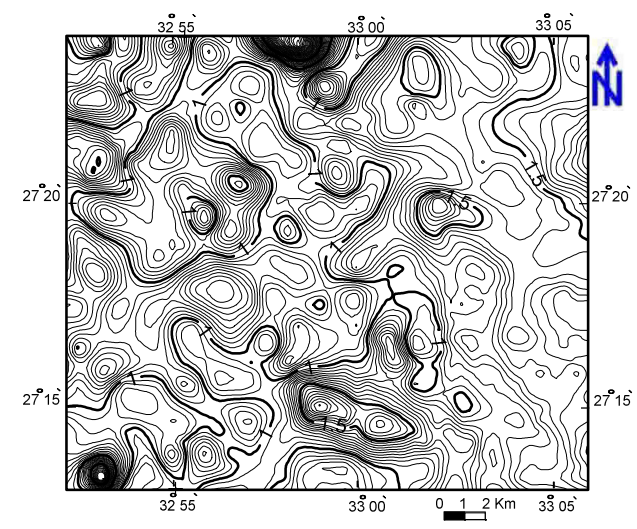

Fig. 32: Airborne eU/K ratio contour, Al Aglab area, north Eastern Desert, Egypt

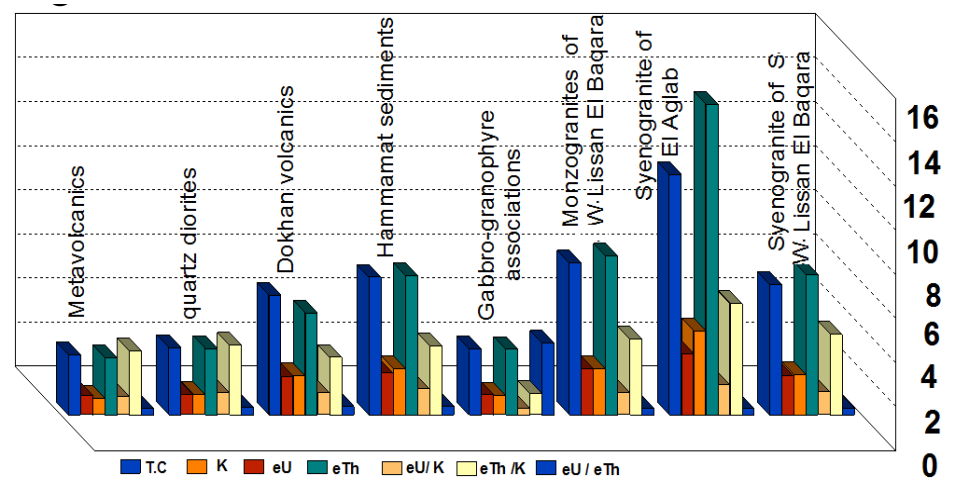

Fig. 33: Bar diagram summarizes the radiometric measurements of different rock types, Al Aglab area 
and NE-SW to ENE-WSW trending fault systems obtained from the geological and radiometric field investigations.

Moreover, airborne gamma ray spectrometric data analysis delineate most of the surface geology of the reconstructed compiled geological map whereas the different types of alterations as hematitization, kaolinitization, chloritization and silicification have been recorded within the syenogranites, where their distribution is mainly controlled by the interactions between the NNW-SSE to N-S and NE-SW to ENE-WSW trending structural lineaments.

\section{Ground Radiometric Survey}

Field radiometric survey clarified that the syenogranites document the highest level of gamma radioactivity among the various rock types cropping out in the study area. Accordingly, the younger granites are the target of the radioactivity studies in the present work. It is noticed that the field radioactivity increases along fractures, joints and fault planes as well as in the pegmatite pockets and the hydrothermal altered zones. In general, the gamma radioactivity of the various rock types exposed in the area is greatly controlled by their mineralogical features (lithologic control) and/or structural features affecting these rocks (structural control).

The variations in gamma radioactivity of the different rocks in the area usually depends on their acidity, accessory minerals (zircon, apatite, sphene) besides iron having the high ability to adsorb uranium from the circulating solutions (Hussein et. al., 1965; Rogers et. al., 1987; Nossair,1998; Roz,2001 and Moharem, 2006).

The NE-SW fault sets and their associated shear zones are found to play an important role in controlling most of the recorded radioactive anomalies. The zone of intersection of faults striking NE-SW with those belonging to the NW-SE trend are relatively of high gamma radioactivity. The increase of radioactiv- ity at the intersection of faults may be due to the brecciation, shearing and cataclases of the granite along faults. These brecciated zones act as pathway for the circulating hydrothermal solutions bearing radioelements. It can be concluded that the most radioactivity anomalies and their relatively high uranium and/or thorium content in the area are mainly structurally controlled by the NE-SW and NW-SE fault trends.

In the study area, it is noticed that the relics of visible secondary uranium mineralization are seen at the radioactivity anomalies. The faults and fractures trending NE-WS and NWSE have relatively the highest gamma radioactivity and are associated with hydrothermal solutions. The consecutive movements along faults may have led to the re-opening of the hydrothermal altered fractures and leaching their uranium by different weathering agents. This may explain the lacking of secondary uranium mineralization in the anomalous zones.

The radiometric investigations and analyses clarified that the radioactive anomalies in the area are essentially associated with the syenogranites of G. Al Aglab. These anomalies are essentially concentrated along fault planes, shear zones (Fig. 34), besides those occurring in felsite dykes, jasperoid viens (Fig. 35) and pegmatite bodies (Figs. 36a,b,c).

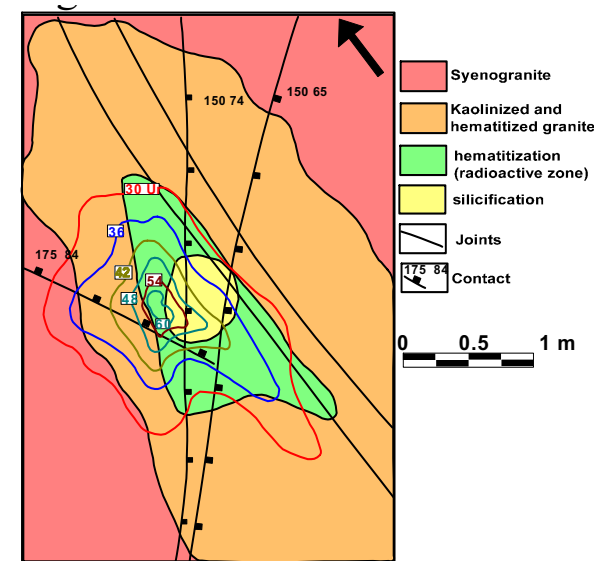

Fig.34: Examples of the carried out detail radiometric and geologic mapping for the recorded high radioactive zones sited in Fig.2, Al Aglab area, North Eastern Desert, Egypt, Shear zone in syenogranites 


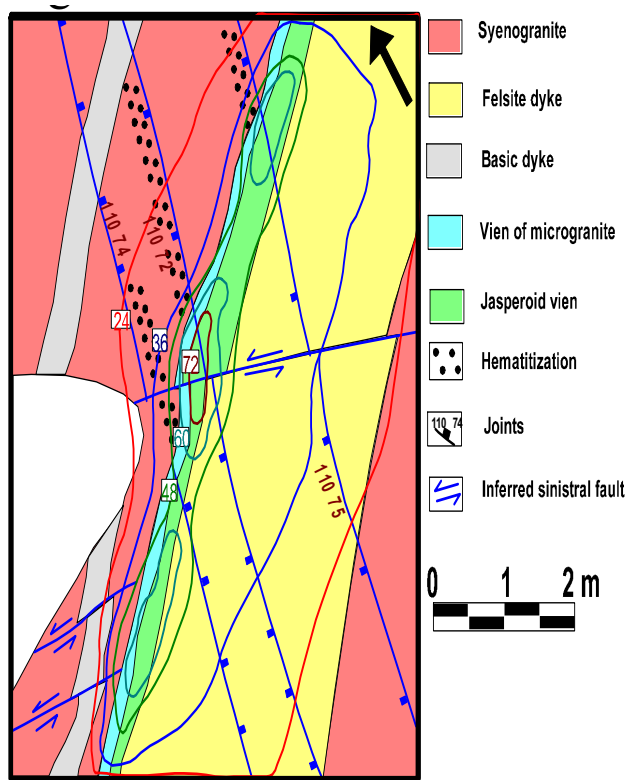

Fig. 35 Examples of the carried out detail radiometric and geologic mapping for the recorded high radioactive zones sited in Fig.2, Al Aglab area, north Eastern Desert, Egypt, Jasperoid vien

\section{RESULTS AND CONCLUSIONS}

The investigated area of $\mathrm{Al}$ Aglab region is located between lat. $27^{\circ} 15^{\prime}$ and $27^{\circ} 25^{\prime} \mathrm{N}$ and long. $32^{\circ} 55^{\prime}$ and $33^{\circ} 05^{\prime} \mathrm{E}$ and occupied by metavolcanics, quartz diorites, Dokhan volcanics, Hammamat sediments, gabbrogranophyre associations, younger granites and post granitic dykes in descending order for the oldest to the youngest.

The granitic rocks of the area are classified into: monzogranite and syenogranite. The syenogranite represents the most evolved phase. Faults, in spite of their type, are arranged according to three main trend clusters around N-S (NNE-SSW-NNW-SSE), NE-SW and NW-SE directions, respectively in addition to fairly E-W one. Moreover, the analysis of the recorded movement criteria on fault planes reflect cyclic extensional strike-slip regime corresponding to multi-directional NW-SE \& NE-SW oriented extension associated with almost all recorded dyke and vein trends in addition to an older NNE-SSW \& WNW-ESE to E-W trending pair of extension
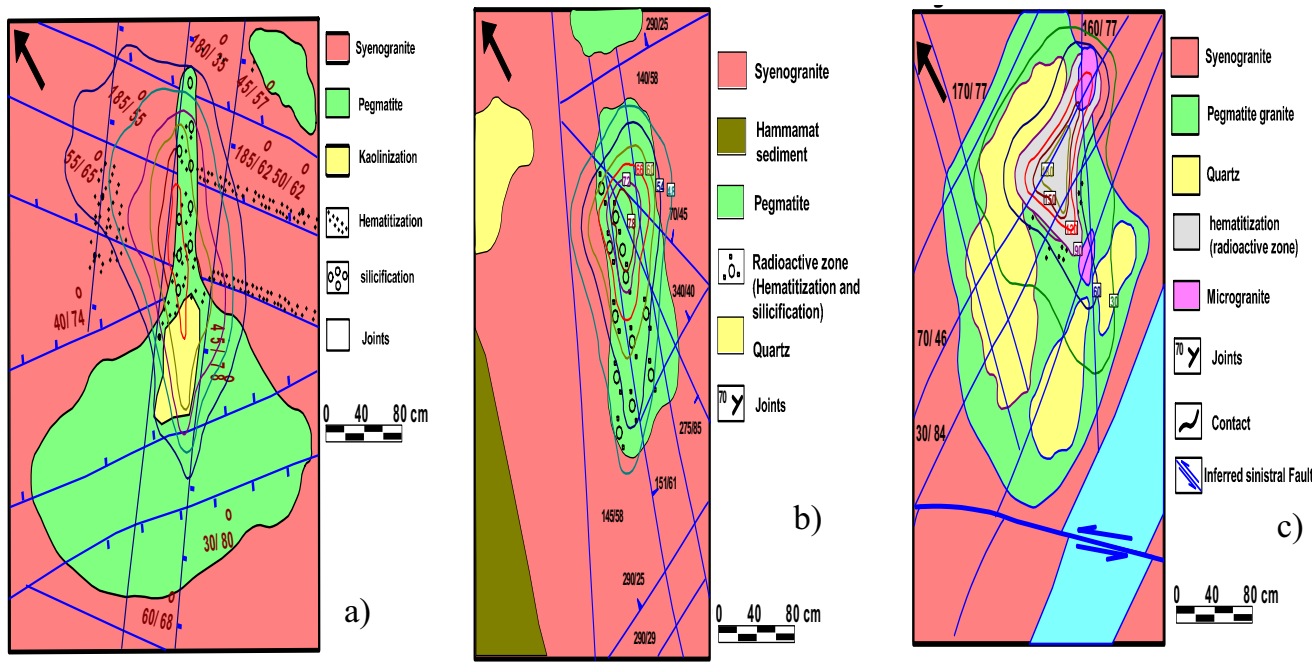

Fig. 36: Examples of the carried out detail radiometric and geologic mapping for the recorded high radioactive zones sited in Fig.2, Al Aglab area, North Eastern Desert, Egypt, Pegmatite bodies (a,b.c) 
characterizing the measured strike-slip and normal fault sets that arranged in NE-SW, NS, ENE-WSW and NNW-SSE trends according to their length and number proportions in decreasing order directions (ENE-WSW, $\mathrm{N}-\mathrm{S}$ and NNW-SSE). The most predominant trend is the ENE-WSW seeming to be re-activated many times contemporaneously with the injection of acidic rocks as well as quartz veins in association with high hydrothermal fluid activity corresponding to the presence of different types of alterations such as hematitization, Kaolinitization, chloritization and silicification that recorded along these NNWSSE to N-S and NE-SW to ENE-WSW fault systems cross cutting Al Aglab granite pluton. The high radioactive anomalies are recorded along the ENE-WSW shear zones, where it reaches more than $84 \mathrm{Ur}$. The syenogranites within this zone are highly altered and show disseminated pegmatite bodies.

Landsat Thematic Mapper (TM) remote sensing data supported by geology and airborne geophysical (airborne gamma-ray spectrometric and aeromagnetic) as well as the ground geological and radiometric investigation data sets was used to delineate surface and subsurface structural elements in the study area.

The Landsat image of the area added some litholgic details useful in identifying and discriminating the different lithologic rocks exposed in the study area. Statistical analysis of the extracted structural lineaments from landsat image in the study shows that most of the well-developed structural lineaments have NNW-SSE to N-S and NE-SW to ENE-WSW trends.

The aerospectrometric data (TC, K\%, eUppm, eThppm, eU/eTh, eU/K and eTh/K) have been statistically analyzed and correlated with the compiled geological map. The interpretation of airborne gamma-ray spectrometric maps (TC, K\%, eUppm, eThppm, eU/eTh, $\mathrm{eU} / \mathrm{K}$ and $\mathrm{eTh} / \mathrm{K}$ ) and magnetic maps revealed that the western central part of Al Aglab plu- ton is the most promising zones for uranium potentiality. It is found that a little fractionation was detected in the main granitic pluton toward the south where the thorium content varies from 10 to $20 \mathrm{ppm}$ eTh, meanwhile it is less than $15 \mathrm{ppm}$ eTh at the northwestern part.

The analyzed aeromagnetic data demonstrated that the NNW-SSE to N-S and NE-SW ENE-WSW fault systems interpreted from magnetic analytical signal map where the structure control radioactive anomalies are well matched with the fault systems delineated from Landsat image.

Detailed field radiometric survey and geologic mapping are carried out for some selected high radioactive zones in order to study their interrelation with the lithostructure units. Several types of alterations (hematitization, kaolinitization, chloritization and silicification) recorded in the granite of Al Aglab pluton is controlled by shear zones mainly striking NNW-SSE to N-S and NE-SW ENEWSW. These fracture zones facilitate the fluid circulation that caused alterations, especially in the western central parts part of the pluton. These alterations are associated with U-mineralization. The radioactive anomalies associated with the syenogranites of G. Al Aglab are essentially concentrated along fault planes, shear zones, besides those occurring in felsite dykes, jasperoid viens and pegmatite bodies. Some relics of visible secondary uranium mineralization is seen at these anomalies; controlled by the faults and fractures trending NEWS and NW-SE.

Spectrometric data (K, U and Th) shows a very high consistency between the radioelement distributions and the differentiated outlines of different rock types. Results from integrated field studies, Landsat Thematic Mapper (TM) remote sensing data and geophysical data analyses provide important constraints on the tectonic evolution of Al Aglab area and demonstrate the strength of combining remote sensing data with geophysical data and geo- 
logical observations in resolving the surface geometry of major fault systems and their impact on the radioelement potential distribution within Al Aglab area.

\section{REFERENCES}

Abd El-Hadi, A.M., 2006. Geological setting and radioelements distribution in Gabl El Resha- Wadi El Atrash area, North Eastern Desert, Egypt. M. Sc. Thesis, Benha Univ., Egypt, 276 p.

Abu El Leil, I., 1980. Geology, petrography and geochemistry of some granitic rocks in the northern part of the Eastern Desert of Egypt. Ph. D. Thesis, Al Azhar Univ., Egypt, 294 p.

Aero-Service, 1984a. Interpretation report of airborne gamma-ray spectrometer and magnetometer survey of the Eastern Desert of Egypt. 127 p.

Aero-Service, 1984b. Final operational report of airborne magnetic/radiation survey in the Eastern Desert, Egypt for the Egyptian General Petroleum Corporation. Aero-Service, Houston, Texas, April 1984, Six Volumes.

Ayoub, R. R., 2003. Geology and radioactivity of Gabal Um Tweir area, north Desert, Egypt. Ph. D. Thesis, Cairo Univ., Egypt, $286 \mathrm{p}$.

Bregar, M.; Bauernhofer, A.; Pelz, K.; Kloetzli, U.; Fritz, H., and Neumayr, P., 2002. A late Neoproterozoic magmatic core complex in the Eastern Desert of Egypt. emplacement of granitoids in a wrench-tectonic setting. Prec. Res. , 118, 59-82.

Caputo, R., 2005. Stress variability and brittle tectonic structures. Earth-Science Reviews, 70 , 103-127.

Dardir, A.A., and Abu Zeid, K.M.,1972. Geology of the basement rocks between Lat. $27^{\circ} 00^{\prime}$ and $27^{\circ} 30^{\prime}$ N. Eastern Desert. Ann. Geol. Surv. Egypt, II, 129-159.
El-Gaby, S.; El-Nady, O., and Khudeir, A., 1984. Tectonic evolution of the basement complex in the Central Eastern Desert of Egypt. Geologische Rundshau, 73, 10191036.

El-Gaby, S.; List, F.K., and Tehrani, R., 1988. Geology, evolution and metallogenesis of the Pan-African Belt in Egypt. In: The Pan-African Belt of NE Africa and Adjacent Areas (El Gaby, S.; Greiling, R. ,Eds.): Tectonic Evolution and Economic Aspects.Vieweg, Braunschweig, Wiesbaden, 17-68.

Farahat, E.S.; Mohamed, H.A.; Ahmed, A.F., and El Mahallawi, M.M., 2007. Origin of I- and A type granitoids from the Eastern Desert of Egypt; implications for crustal growth in the northern Arabian-Nubian Shield. J. Afri. Earth Sci., 49, 43-58.

Fritz, H.; Wallbrecher, E.; Khudeir, A.A.; Abu El Ela, F., and Dallmeyer, D.R., 1996. Formation of Neoproterozoic metamorphic core complexes during oblique convergence (Eastern Desert, Egypt). J. Afri. Earth Sci., 23, 311-329.

Faure, S.; Tremblay, A. , and Angelier, J., 1996. State of intraplate stress and tectonism of northeastern America since Cretaceous times, with particular emphasis on the New England-Quebec igneous province. Tectonophysics, 255, 111-134.

Greiling, R.O.; Abdeen, M.M.; Dardir, A.A.; El Akhal, H.; El Ramly, M.F.; Kamal El Din, G.M.; Osman, A.F.; Rashwan, A.A.; Rice, A.H.N., and Sadek, M.F., 1994. A structural synthesis of the proterozoic Arabian-Nubian shield in Egypt. Geologische Rundschau, 83, 484-501.

Hussein, H.A.; Faris, M.I., and Makram, W.S., 1965. Radioactivity of some accessory minerals especially zircon in some Egyptian granites and pegmatites. J. Geol. U.A.R., 9 (No.2), 13-16. 
Lundmark, A.M.; Andresen, A.; Hassan, M.A.; Augland, L.E.; Abu El-Rus, M.A. and Baghdady, G.Y., 2012. Repeated magmatic pulses in the East African Orogen of Central Eastern Desert, Egypt: An old idea supported by new evidence. Gond. Res., 22 (issue 1), 227-237.

Moharem, A. F.,2006. Uranium Distribution in the Um Samra- Um Bakra Granitic Plutons and Associated pegmatites, Central Eastern Desert, Egypt. Proc. $7^{\text {th }}$ Arab Conf. on the peaceful uses of Atomic Energy, II, 311-325.

Mostafa, M.S., 2012. Structural elements of the Eastern Desert of Egypt and its impact on mineralizatin. Internal Review article, Nuclear Materials Authority (NMA),1-25.

Moussa, E.M.M.; Stern, R.J.; Manton, W.I., and Ali, K.A., 2008. SHRIMP zircon dating and $\mathrm{Sm} / \mathrm{Nd}$ isotopic investigations of Neoproterozoic granitoids, Eastern Desert, Egypt. Prec. Res.,160, 341-356.

Nabighian, M.N.,1972.The analytic signal of two- dimensional magnetic bodies with polygonal cross-section: its properties and use for automated anomaly interpretation. Geophysics ,37, 507-517.

Nabighian,M.N.,1974. Additional comments on the analytic signal of two-dimensional magnetic bodies with polygonal cross-section, Geophysics ,39, 85-92.

Nabighian, M.N.,1984.Toward a three-dimensional automatic interpretation of potential field data via generalized Hilbert transforms: fundamental relation, Geophysics, 49, 957-966.

Nossair, L. M.,1998. Geochemical characteristics of Gabal Abu Harba younger granites and their radioelements distribution, North
Eastern Desert, Egypt. Egyptian Mineral., 10, 117-130.

Rogers, J.J.W.; Ghuma, M.A.; Nagy, R.M.; Greenberg, J.K., and Fullagar, P.D.,1978. Plutonism in Pan-African belts and the geological evolution of northeast Africa. Earth Planet. Sci. Let., 39, 109-117.

Roz, M.E.,2001. Geology and uranium potentialities in Gabal Abu Harba environs, North Eastern Desert, Egypt. Ph. D. Thesis, Cairo Univ., Egypt, 264 p.

Sabet, A.H.; Bessonenko, V.V., and Bykov, A.A., 1976. The intrusive complex of the Centeral Eastern Desert of Egypt. Ann. Geol. Surv., 2, 53-73.

Sarma, D.D., and Koch, G.S.,1980. A statistical analysis of exploration geochemical data for uranium. Mathematical Geology, 12 (2), 99-114.

Stern, R.J.; Avigad, D.; Miller, N.R., and Beyth, M., 2006. Evidence for the Snowball Earth Hypothesis in the Arabian-Nubian Shield and the East African Orogen. J. Afri. Earth Sci., 44, 1-20.

Stern, R.J.; Gottfried, D., and Hedge, C.E., 1984. Late Precambrian rifting and crustal evolution in the Northeast Desert of Egypt. Geol., 12, 168-172.

Stern, R.J., and Hedge, C.E., 1985. Geochronologic and isotopic constraints on late Precambrian crustal evolution in the Eastern Desert of Egypt. Amer. J. Sci., 285, 97-172.

Sultan, M.; Arvidson, R.E.; Duncan, I.J.; Stern, R. and El Kaliouby, B., 1988. Extension of the Najd Fault System from Saudi Arabia to the central Eastern Desert of Egypt based on integrated field and Landsat observations. Tectonics, 7, 1291-1306. 


\section{المظاهر الحاكمة لتوزيع العناصر المشعة في منطقة الاجلب، شمال الصحراء الشرقية، مصر}

$$
\text { أحمد عبد الخالق خميس و ريمون ر اغب ايوب إبات }
$$

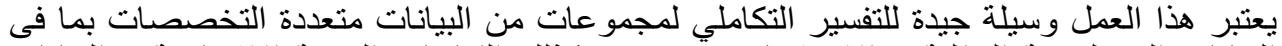

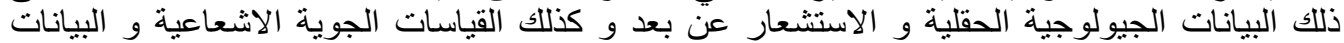
الجيوفيزيائية المغناطيسية بهدف تحديد المظاهر الحاكمة فى توزيع العناصر المشعة ولئية المحتملة فى منطقة جبل الاجلب.

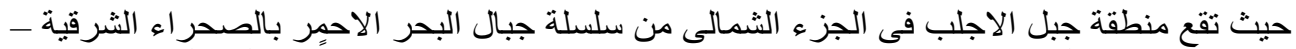

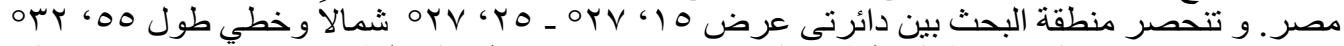

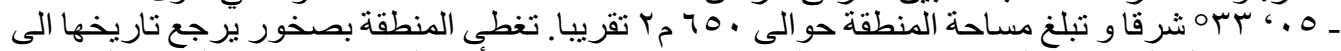

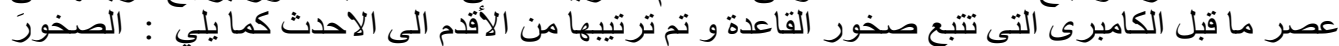

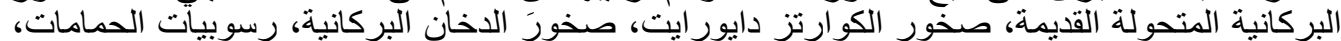

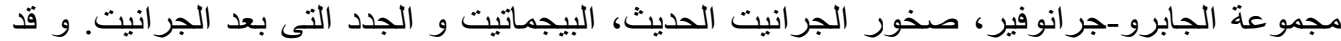

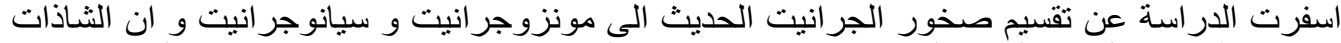

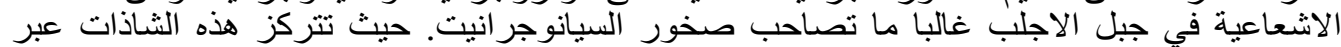

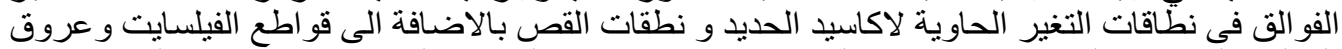

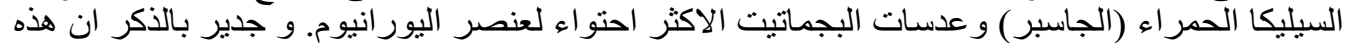

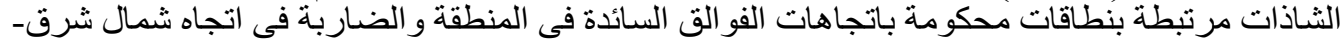

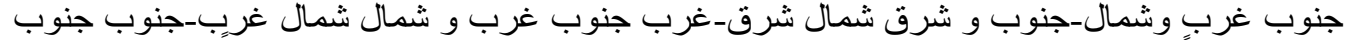

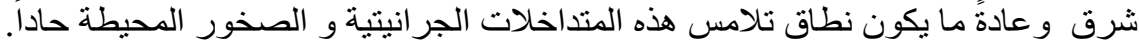

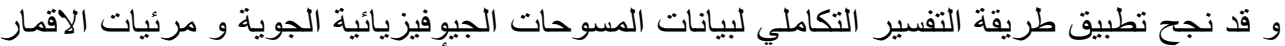

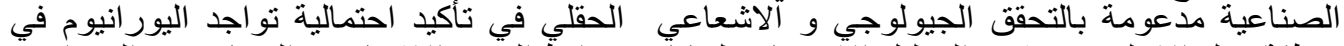

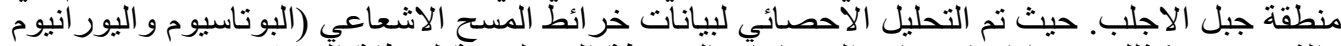

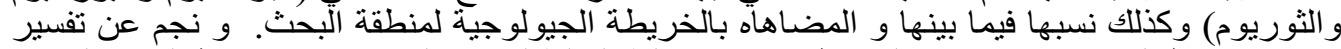

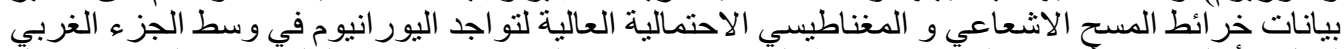

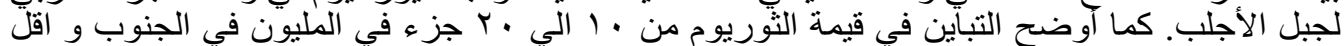

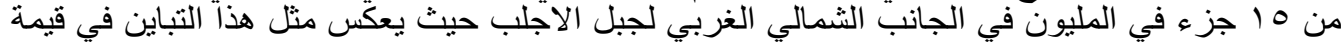

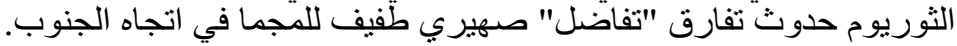

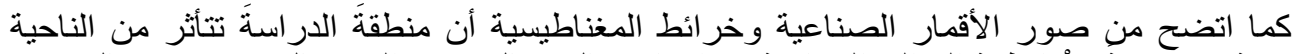

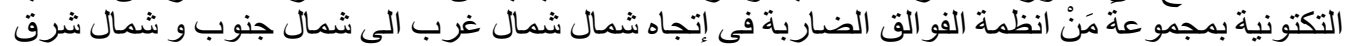

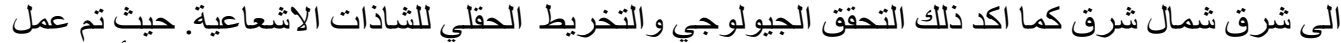

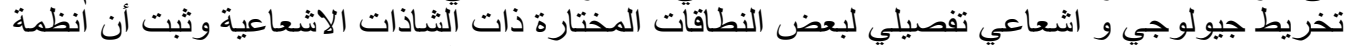

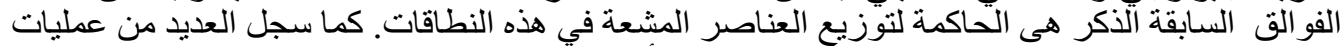

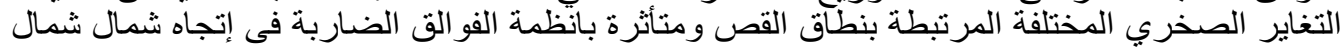

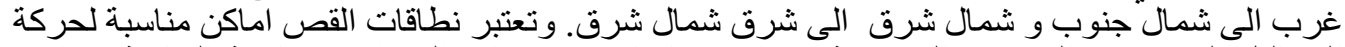

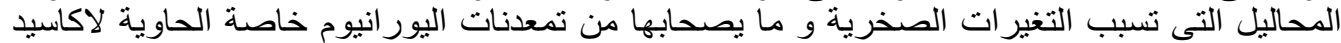
الحديد بما لها من خاصية ادمصاص اليور انيوم من المحاليل الحاملة له له

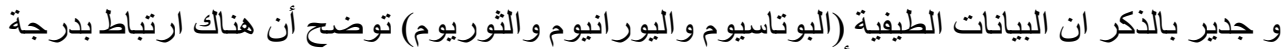

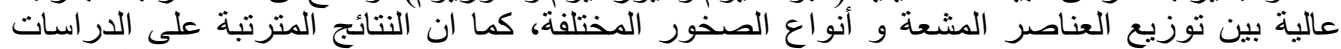

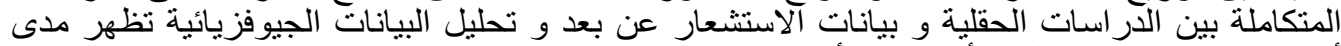

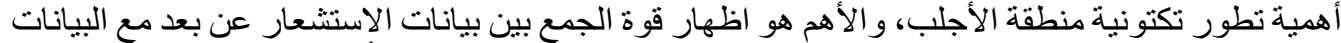

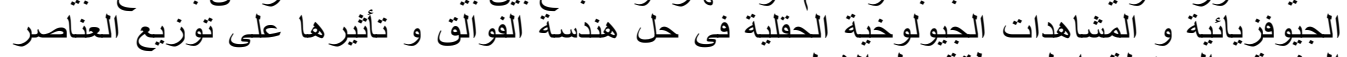
المشعة و المحتملة داخل منطقة جبل الاجلب. 